Bangladesh J. Bot. 43(1): 45-52, 2014 (June)

\title{
GENETIC VARIABILITY, CORRELATION AND PATH ANALYSIS OF FLORAL, YIELD AND ITS COMPONENT TRAITS IN CMS AND RESTORER LINES OF RICE (ORYZA SATIVA L.)
}

\author{
SS Bornare*, SK MitTra AND AK Mehta \\ Department of Plant Breeding and Genetics, College of Agriculture, \\ Jawaharlal Nehru Krishi Vishwa Vidyalaya, Jabalpur-482004 (M.P.), India
}

Key words: Rice, Correlation, Path analysis, Restorer lines, Yield component

\begin{abstract}
The coefficients of phenotypic and genotypic variability were comparatively high for effective tillers/plant followed by grain yield/plant, plant height and angle of floret. High heritability accompanied with high genetic advance indicated predominance of additive gene action for the traits viz., 1,000 seed weight, plant height, anther breadth, anther length, effective tillers/plant and angle of floret opening. Selections can be effective on the basis of correlation and path analysis for characters like effective tillers/plant, spikelet density, angle of floret opening, duration of floret opening, panicle length, 1,000 seed weight and days to 50 per cent flowering. With respect to findings of the investigation, CMS lines viz., APMS 6A, IR 69622A, IR 62829A, IR 70369A and IR 68886A were identified as superior female lines with respect to floral, yield and its contributing traits whereas, among the restorer lines NPT-10, NPT-13-01, R-710 and Sugandh-3 were identified as putative lines.
\end{abstract}

\section{Introduction}

Rice (Oryza sativa L.) is the most important staple food crop in the world, and used by more than half of the world population (Kohnaki et al. 2013). In view of the growing population, the basic objective of the plant breeders would always be towards yield improvement in staple food crops. It has been estimated that the world will have to produce 60\% more rice by 2030 than what it produced in 1995 (Babu et al. 2012). Hence, an increase in the production of rice plays an important role in the food security and poverty alleviation.

It is known that yield of rice is complex quantitative trait and under pleiotropic gene control at the same time it is highly influenced by environment and contributed by many other traits. Furthermore, selection based on only yield is misleading. Information on association of characters, direct and indirect effects contributed by each character towards yield will be an added advantage in aiding the selection process. A precise knowledge of the genotypes and extent of correlated response to selection for yield, yield attributes and quality traits would be of great help in planning a systematic breeding programme in situation of this kind. High magnitude of variability in a population provides the opportunity for selection to evolve a variety having desirable characters.

The present study was undertaken to find out the genetic variability among different traits of rice plants, direct and indirect contribution of these parameters towards paddy yield and to identify superior putative lines in respect of various morphological, floral and yield contributing traits of different CMS and restorer lines of rice.

\section{Materials and Methods}

Fifteen CMS and ten restorer (Table 1) lines were grown in RBD with three replications at Seed Breeding Farm, Department of Plant Breeding and Genetics, College of Agriculture, J.N.K.V.V., Jabalpur (M.P.). Twenty one-day-old seedlings of CMS and restorer lines were

*Author for correspondence: <satish07.bhu@gmail.com>. 
transplanted in the experimental site. Each genotype was planted in two rows of $6 \mathrm{~m}$ length with row spacing of $20 \mathrm{~cm}$. with one seedling per hill. Gap filling was done within a week in order to maintain uniform plant population. The standard agronomic practices were adopted for normal crop growth.

Table 1. Experimental material with their sources.

\begin{tabular}{|c|c|c|}
\hline A. CMS lines & Source/origin & Developed by \\
\hline IR 69617A & WA cytoplasam & IRRI, Philippines \\
\hline IR 69622A & " & " \\
\hline IR 58025A & $"$ & $"$ \\
\hline IR 62829A & $"$ & $"$ \\
\hline IR 79156A & $"$ & $"$ \\
\hline IR 70369A & $"$ & $"$ \\
\hline IR 68886A & $"$ & $"$ \\
\hline IR 68888A & $"$ & $"$ \\
\hline IR 68897A & $"$ & $"$ \\
\hline IR 68899A & $"$ & $"$ \\
\hline CRMS 31A & Kalinga cytoplasam & CRRI, Cuttack \\
\hline CRMS 32A & " & " \\
\hline DMS 3A & O. nivara cytoplasam & DRR, Hyderabad \\
\hline PUSA 6A & WA cytoplasam & IARI, New Delhi \\
\hline APMS 6A & " & $\begin{array}{l}\text { APRRI, Maruteru } \\
\text { (ANGRAU), Hyderabad }\end{array}$ \\
\hline \multicolumn{2}{|c|}{ B. Restorer lines } & Developed by \\
\hline \multicolumn{2}{|c|}{ KMR-3 } & Mandya, UAS, Bangalore \\
\hline \multicolumn{2}{|c|}{ Sugandha-3 } & IARI, New Delhi \\
\hline \multicolumn{2}{|c|}{ NPT-10 } & " \\
\hline \multicolumn{2}{|c|}{ NPT-29 } & $"$ \\
\hline \multicolumn{2}{|c|}{ NPT-65 } & $"$ \\
\hline \multicolumn{2}{|c|}{ NPT-70 } & $"$ \\
\hline \multicolumn{2}{|c|}{ NPT-13-01 } & " \\
\hline \multicolumn{2}{|c|}{ Abhya } & IGKV, Raipur \\
\hline \multicolumn{2}{|c|}{$\mathrm{R}-296$} & " \\
\hline \multicolumn{2}{|c|}{$\mathrm{R}-710$} & $"$ \\
\hline
\end{tabular}

The average of ten plants was subjected to variance analysis and test of significance as per the method of Fisher (1935). Genotypic coefficient of variation (GCV) and phenotypic coefficient of variation (PCV) were calculated following Burton (1952). The estimates of PCV and GCV were classified as low, moderate and high according to Sivasubramanian and Madhavamenon (1973).

Correlation coefficients were calculated for all the character combinations at genotypic and phenotypic levels as per the formula given by Miller et al. (1958). Path coefficient analysis was undertaken in parents for designing new plant type with the knowledge of direct and indirect influence of yield contributing characters on yield. Wright (1921) proposed the original technique; analysis was carried out by modified method devised by Dewey and Lu (1959). Path coefficients were rated based on the scales given by Lenka and Mishra (1973). 


\section{Results and Discussion}

The analysis of variance revealed that the mean sum of square due to genotypes differed significantly for all the morphological, floral and yield traits. High magnitude of genotypic coefficient of variation indicates presence of substantial amount of genetic variability in the population and there is little influence of the environment on the expression of character. Phenotypic coefficients of variation estimates were higher than the genotypic coefficient of variation for all characters. This is due to the occurrence of error variance into the phenotypic coefficient of variance. Similar findings were also reported by Souroush et al. (2004). The coefficients of phenotypic and genotypic variabilities (Table 2) were comparatively high for effective tillers/plant (26.60 and 29.96), grain yield/plant (20.60 and 26.62), plant height (21.15 and 21.44) and angle of floret opening (19.79 and 20.26). These results were in agreement with the findings of Mishra and Verma (2002) for grain yield/plant. Hasib et al. (2004) for grain yield/plant and plant height, Verma et al. (2000) for effective tillers/plant and grain yield.

The estimate of heritability and genetic advance can be utilized for the prediction of genetic gain, which indicates the genetic improvement that would result from the selection of best individuals. The broad sense heritability estimates were very high for plant height (97.35\%) followed by angle of floret opening (95.35\%), days to hundred per cent flowering (93.71), gynoecium length (92.18\%) and anther length (91.22\%) while the estimates were high for number of spikelet/panicle (88.94), duration of floret opening (88.83\%), 1,000 seed weight (88.02\%), anther breadth (86.10\%), spikelet density (80.52\%), effective tillers/plant (78.81\%), panicle length $(72.43 \%)$ and days to maturity $(72.43 \%)$. These results were consistent with the findings of Durai et al. (2001) for 1,000 seed weight and number of spikelet/panicle. Verma et al. (2002) for days to maturity, plant height, seed length 1,000 seed weight and plant height; Kumari et al. (2003) for effective tillers/plant, number of spikelet/panicle, plant height, panicle length and 1,000 grain weight; Chaudhary et al. (2004) for panicle length, and effective tillers/plant while, Satyanarayana et al. (2005) for number of spikelet/panicle, effective tillers/plant, 1,000 seed weight and plant height.

The estimates of genetic advance expressed as percentage of mean were very high for effective tillers/plant (48.64) and plant height (42.99), the estimates were high for grain yield/plant (32.85), number of spikelet/panicle (29.40), spikelet density (26.39) and angle of floret opening (25.51), the estimates were moderate for 1,000 seed weight (22.50), anther breadth (20.37) and anther length (20.32). These results are in agreement with the findings of Rao (2000) for 1,000 seed weight and number of spikelet/panicle while, Mishra and Verma (2002) for plant height, effective tillers/plant and 1,000 seed weight; Chand et al. (2004) for number of spikelet/panicle, 1,000 seed weight and grain yield/plant; Sharma and Bhuyan (2004) for number of spikelet/panicle, grain yield/plant, effective tillers/plant and Saleem et al. (2008) for plant height and spikelet density.

High heritability accompanied by moderate - high genetic advance indicated the predominance of additive gene action for the traits viz., 1,000 seed weight, plant height, anther breadth, anther length, spikelet density, effective tillers/plant and angle of floret opening. Genotypic and phenotypic correlation coefficients between morphological, floral and yield traits are presented in Table 3 . The results revealed that the estimate of genotypic correlation coefficients were higher than the phenotypic correlation coefficients for all the characters. Effective tillers/plant (0.66) and spikelet density (0.34) indicated strong positive correlation with grain yield/plant at both genotypic and phenotypic level while, angle of floret 


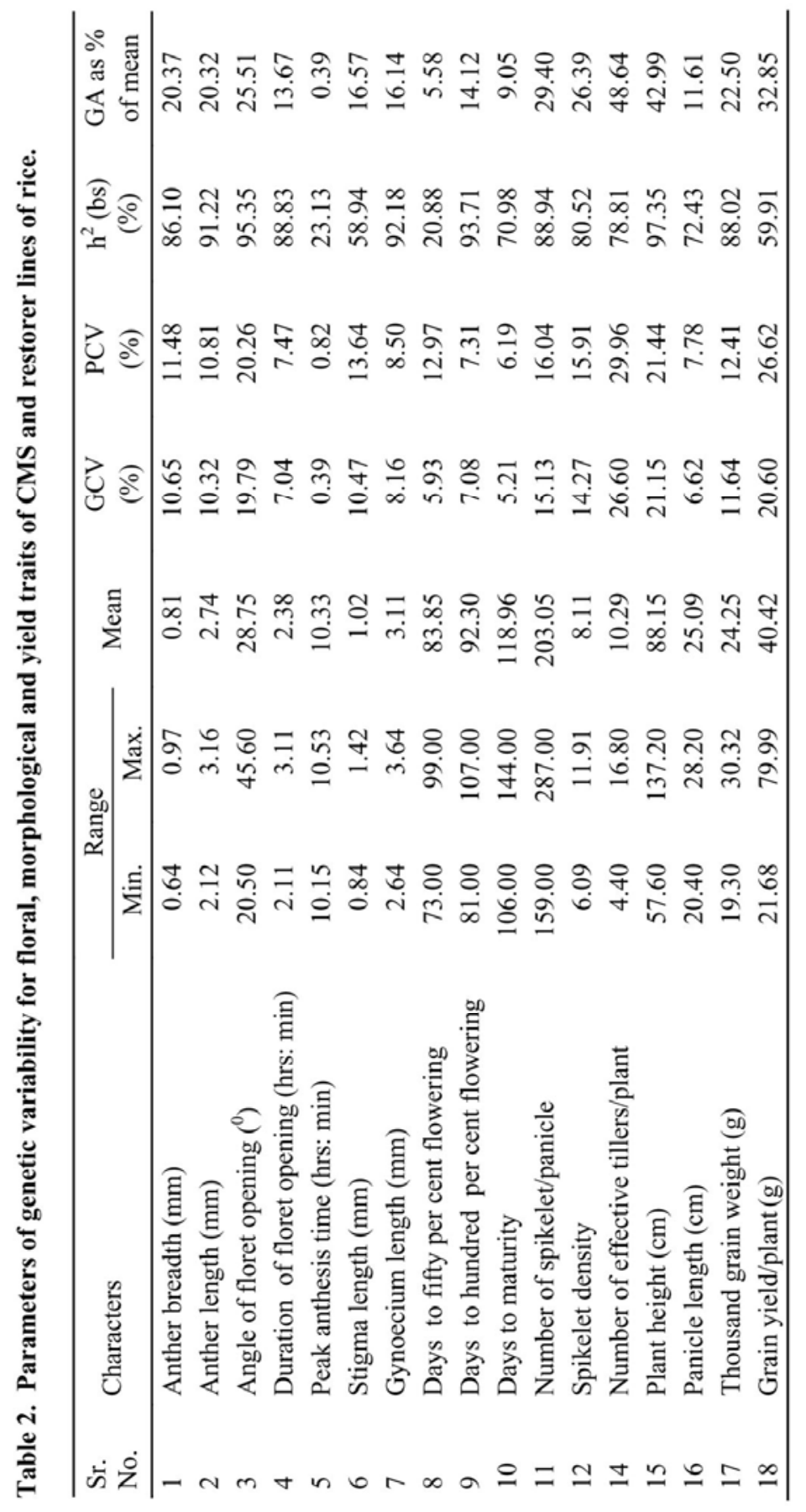




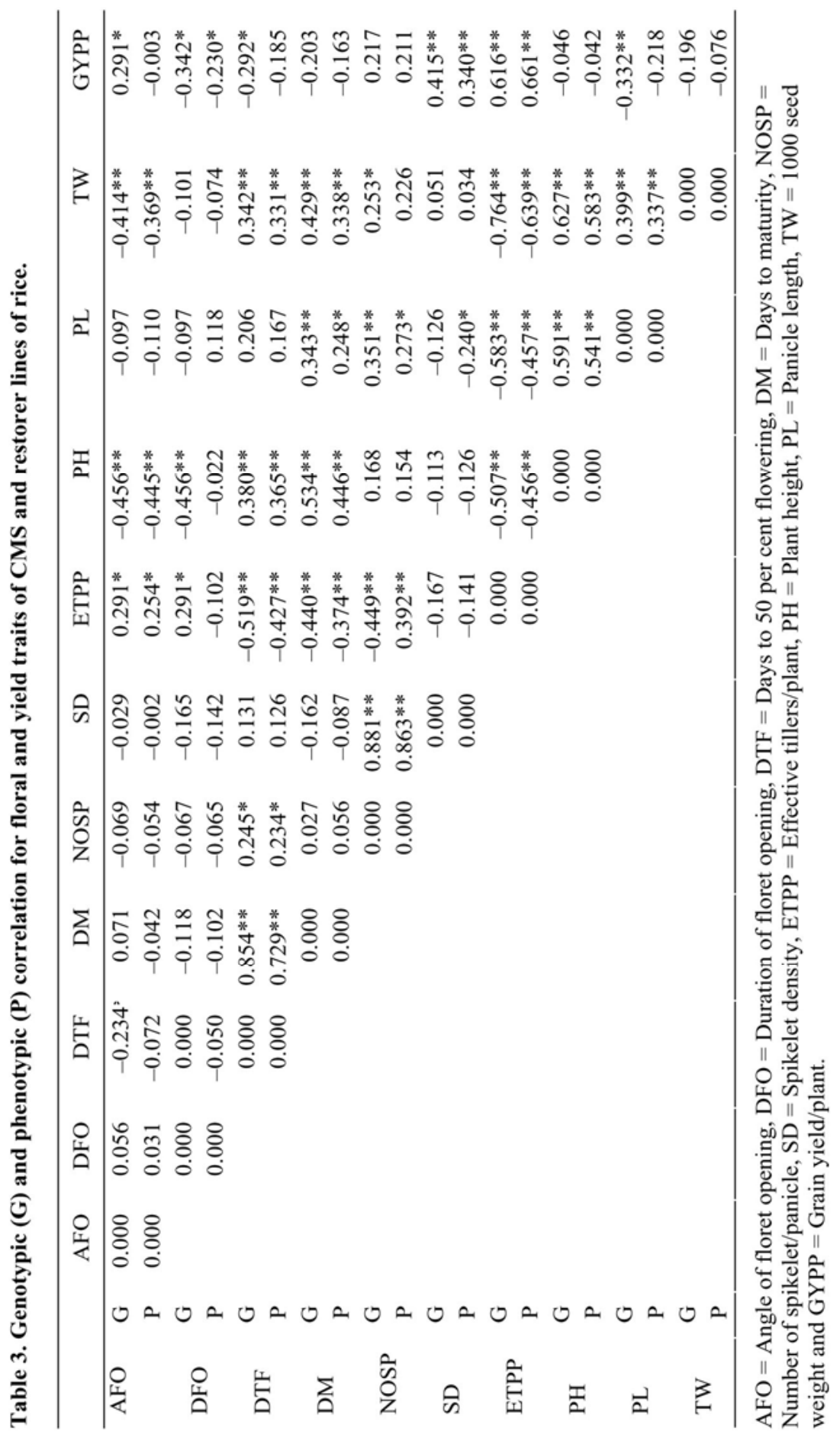




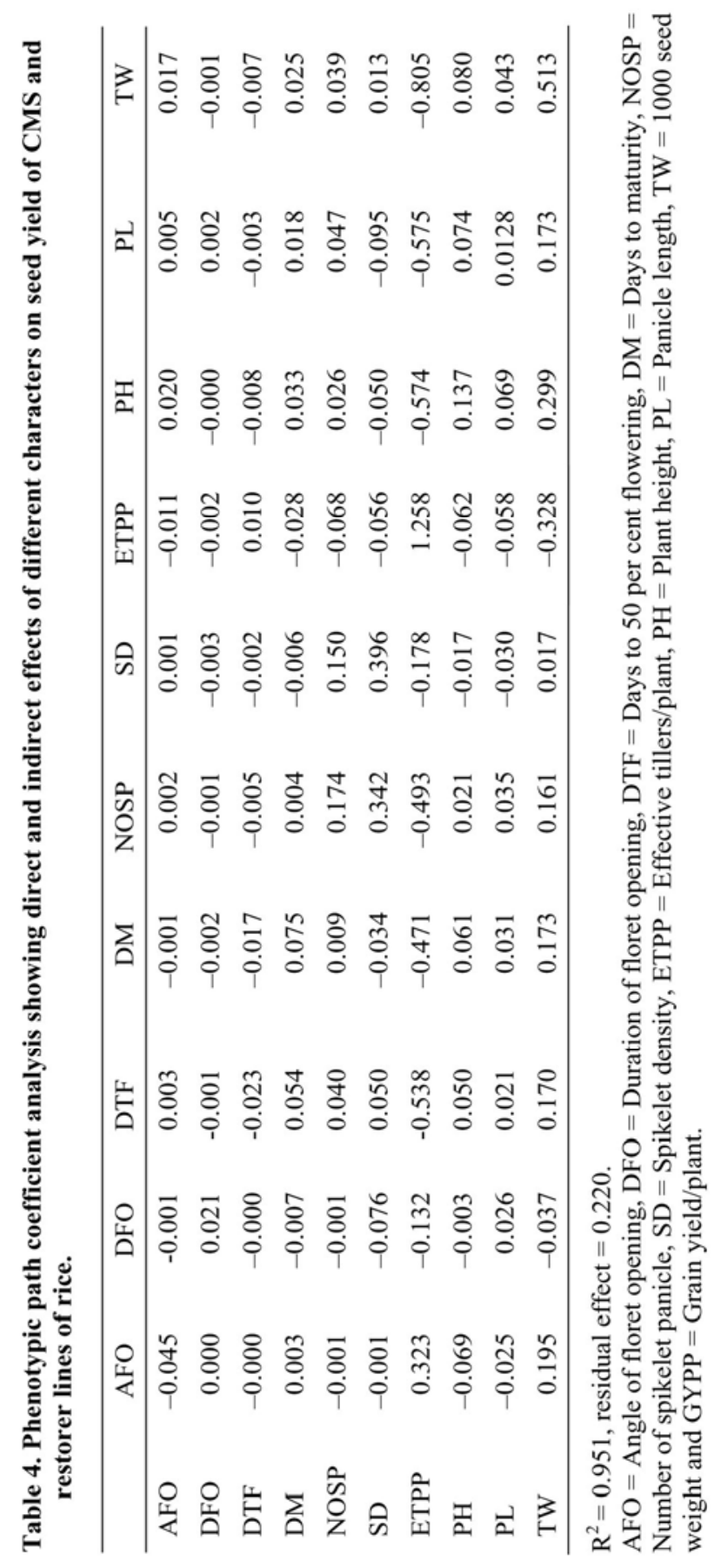


opening expressed positive genotypic correlation. Duration of floret opening revealed negative correlation at both level however, at genotypic level days to 50 per cent flowering indicated negative correlation.

Positive association of effective tillers/plant with grain yield/plant was in agreement with the findings of Chaudhary et al. (2003), Verma and Shrivastava (2004), Satyanarayana et al. (2005) and Sabu et al. (2009) while, positive association of spikelet density was in agreement with the findings of Bagali et al. (1999). Path coefficient analysis was carried out using phenotypic correlation, using grain yield/plant as a dependent variable. Path coefficients are rated as per the scales given by Lenka and Mishra (1973). The estimates of path coefficient are furnished in Table 4.

The path coefficient analysis of different traits contributing towards grain yield/plant revealed that effective tillers/plant (1.258) had very high positive direct effect followed by high positive direct effect of 1,000 seed weight (0.513) and spikelet density (0.396). However, the estimates were low for number of spikelet/panicle (0.174), plant height $(0.137)$ and panicle length $(0.128)$ and negligible for days to maturity $(0.075)$, duration of floret opening (0.021). While, angle of floret opening $(-0.045)$ expressed highly negative direct effect on grain yield/plant followed by low estimate by days to 50 per cent flowering (0.023). These results are in agreement with the findings of Shanthala et al. (2004) for 1,000 seed weight and Agahi et al. (2007) for effective tillers/plant, which revealed positive direct contribution of these traits toward yield.

With respect to findings of the investigation, CMS lines viz., APMS 6A, IR 69622A, IR 62829A, IR 70369A and IR 68886A were identified as superior female lines with respect to floral, yield and its contributing traits whereas, among the restorer lines NPT-10, NPT-13-01, R710 and Sugandh-3 were identified as putative restorer lines.

\section{References}

Agahi K, Mohammad HF and Ezatollah F 2007. Correlation and path analysis for some yield related traits in rice genotypes (Oryza sativa L.). Asian J. Plant Sci. 6(3): 513-517.

Babu Ravindra V, Shreya K, Singh DK, Usharani G, Siva Shankar A 2012. Correlation and path coefficient analysis studies in popular rice hybrids of India. Int. J. Sci. and Res. Pub. 2(3): 1-5.

Bagali GS, Hittalmani and Shashidhar HE 1999. Character association and path coefficient analysis in indica x japonica doubled haploid population of rice. Oryza, 36: 10-12.

Burton GW 1952. Quantitative inheritance in grasses. Proc. $6^{\text {th }}$ Int. Grassland Cong. 1: 127-183.

Chand SP, Roy SK, Mondal GS, Mahato PD, Panda S, Sarkar G and Senapati BK 2004. Genetic variability and character association in rainfed lowland Aman paddy (Oryza sativa L.). Environ. Ecol. 22 (2): 430-434.

Chaudhary M and Motiramani NK 2003. Variability and association among yield attributes and grain quality in traditional aromatic rice accessions. Crop Improvement 30(1): 84-90.

Chaudhary M, Sarawgi AK and Motiramani NK 2004. Genetic variability of quality, yield and yield attributing traits in aromatic rice (Oryza sativa L.). Adv. Plant Sci. 17(2): 485-490.

Dewey DR and Lu KH 1959. A correlation and path coefficient analysis of component of crested wheat grass seed production. Agron. J. 51: 515 - 518.

Durai AA, Ngachan SV, Pattanayak A and Sarma BK 2001. Comparative study of heretability, genetic advance and association of characters in conventionally bred and doubled haploid lines of rice (Oryza sativa L.). Ind. J. Hill Farming 14(2): 71-75.

Fisher RA 1935. The design of experiments. Oliver and Boyd. Edinburgh. xi pp. 251.

Hasib KM, Ganguli PK and Kole PC 2004. Evaluation of the performance of advanced generation lines of mutant x Basmati crosses of scented rice. J. Inter Academicia 8(1): 7-10. 
Kohnaki ME, Kiani G and Nematzadeh G 2013. Relationship between morphological traits in rice restorer lines at $\mathrm{F}_{3}$ generation using multivariate analysis. Int. J. Adv. Biol. Biomed. Res. 1(6): 572-577.

Kumari RU, Rangasamy P and Gomez SM 2003. Phenotypic differentiation in indica-japonica wide compatible varieties in rice (Oryza sativa L.). Plant Archives 3(1): 141-142.

Lenka D and Mishra B 1973. Path coefficient analysis of yield in rice varieties. Ind. J. Agric. Sci. 43: 376-379.

Miller DA, Williams JC, Robinson HF and Comstock KB 1958. Estimates of genotypic and environmental variances and covariances in upland cotton and their implication in selection. Agron. J. 50: 126-131.

Mishra LK and Verma RK 2002. Genetic variability for quality and yield traits in non segregating populations of rice (Oryza sativa L.). Plant Archives 2(2): 251-256.

Rao SS 2000. Estimation of grain yield and interrelationship with yield components in upland rice. Mysore J. Agric. Sci. 34(2): 142-146.

Sabu KK, Abdullah MZ, Lim LS and Wickneswari R 2009. Analysis of heritability and genetic variability of agronomically important traits in Oryza sativa $\times$ O. rufipogon cross. Agron. Res. 7 (1): 97-102.

Saleem MY, Mirza JI and Muhammad AH 2008. Heritability, genetic advance and heterosis in line $\times$ tester crosses of basmati rice. J. Agric. Res. 46(1).

Satyanarayana PV, Srinivas T, Reddy PR, Madhavilatha L and Suneetha Y 2005. Studies on variability, correlation and path coefficient analysis for restorer lines in rice (Oryza sativa L.). Res. Crops 6(1): 80-84.

Shanthala J, Latha J and Hittalmani S 2004. Path coefficient analysis for grain yield with yield components in hybrid rice. Environ. Ecol. 22(4): 734-736.

Sharma MK and Bhuyan J 2004. Genetic variability and divergence studies in rice (Oryza sativa L.). Adv. Plant Sci. 17(1): 323-328.

Sivasubramanian J and Madhavamenon P 1973. Genotypic and phenotypic variability in rice. Madras Agric. J. 12: 15-16.

Souroush HR, Mesbah M, Hossainzadeh A and Bozorgipour R 2004. Genetic and phenotypic variability and cluster analysis for quantitative and qualitative traits of rice. Seed and Plant, 20(2): 167-182.

Verma DK, Thakur R, Singh NK and Mishra SB 2002. Heritability and genetic advance studies in $F_{2}$ population, $\mathrm{F}_{3}$ population, parents and pooled population of Intra indica crosses of rice. Mysore $\mathrm{J}$. Agric. Sci. 36(3): 222-230.

Verma OP and Srivastava HK 2004. Productive association of quantitative traits in diverse ecotypes of rice (Oryza sativa L.). J. Sustainable Agril. 25(2): 75-91.

Verma OP, Santhoshi US, Dwivedi JL and Singh PP 2000. Genetic variability, heritability and genetic advance for quantitative traits in rice. Oryza 37: 38-40.

Wright S 1921. Correlation and causation. J. Agric. Res. 20: 557-587. 